\title{
Pola Komunikasi Guru Ngaji dalam Membina Akhlak Remaja Yayasan At-Tibyan di Kelurahan Mekarsari
}

\author{
Siti Aminah* \\ Prodi Komunikasi Penyiaran Islam, Fakultas Dakwah, Universitas Islam \\ Bandung, Indonesia. \\ *sitiamiinah28@gmail.com
}

\begin{abstract}
The background of this research is the communication pattern of the Qur'an teacher in fostering adolescent morals based on the results of the study, namely using the triadic interpersonal communication pattern is quite efficient because it can target many mad'u and can see its development. However, seen from this study, it is also known that the morals of teenagers in the AtTibyan foundation are still teenagers whose morals are not good. Because from a moral perspective, there are still some teenagers who do not obey the existing morals. Fostering youth morality is a mandatory thing that must be put forward by the AtTibyan Foundation, played by a Koran teacher as a preacher who conveys Islamic teachings. Thus, this thesis discusses the Communication Pattern of the Ngaji Teacher in fostering adolescent morality which is the basis of every education which is used as a foundation as a fortress from the influence of the times that cannot be separated from negative and misleading external culture. Thus, fostering adolescent morals has an important meaning and role in the formation of behavior for adolescents, because in fostering adolescent morals it is not only directed to the happiness of life in the world, but to happiness in the hereafter. This study uses a type of qualitative research method, using field studies (field research) in the data collection process. This study determines the subject and object of research by referring to the interview guidelines for conducting interviews, documentation, and observations. The results of this study indicate that the communication pattern of the Qur'an teacher which is carried out in fostering the morals of the AtTibyan foundation youth in Mekarsari Village is a triadic Interpersonal Communication Pattern. This communication pattern is the right communication pattern to be used in the learning process and plays a very important role in making teenagers have good morals in the foundation environment and in their daily environment.
\end{abstract}

Keywords: Communication Patterns of the Qur'an teacher in fostering adolescent morals.

\begin{abstract}
Abstrak. Latar belakang penelitian ini pola komunikasi guru ngaji dalam membina akhlak remaja berdasarkan hasil penelitian yaitu menggunakan pola komunikasi Antarpribadi triadik sudah terbilang efisien sebab bisa menyasar terhadap banyak mad'u serta bisa melihat perkembangannya. Akan tetapi dilihat dari penelitian ini juga diketahui bahwa akhlak remaja di yayasan At-Tibyan masih terdapat remaja yang akhlaknya kurang baik. Karena melihat dari dari segi akhlakul karimahnya masih ada beberapa remaja yang tidak mentaati akhlak yang ada. Membina Akhlak remaja merupakan hal yang wajib yang harus dikedepankan oleh Yayasan AtTibyan yang diperankan oleh guru ngaji sebagai seorang da'i yang menyampaikan ajaran Islam. Demikian dengan skripsi ini yang membahas tentang Pola Komunikasi Guru Ngaji dalam membina Akhlak remaja yang merupakan dasar dari setiap pendidikan yang dijadikan pondasi sebagai benteng dari pengaruh perkembangan zaman yang tidak lepas dari budaya luar yang negatif dan cenderung menyesatkan. Dengan demikian maka membina akhlak remaja mempunyai arti dan peranan penting dalam pembentukan tingkah laku bagi remaja, sebab dalam membina akhlak remaja ini tidak hanya diarahkan kepada kebahagiaan hidup di dunia, akan tetapi untuk kebahagiaan di akhirat kelak. Penelitian ini menggunakan jenis metode penelitian kualitatif, dengan menggunakan study lapangan (field research) dalam proses pengumpulan datanya. Penelitian ini menentukan subjek dan objek penelitian dengan mengacu pada pedoman wawancara untuk melakukan wawancara, dokumentasi, dan observasi. iv Hasil dari penelitian ini menunjukan bahwa pola komunikasi guru ngaji yang dilakukan dalam membina akhlak remaja yayasan At-Tibyan di Kelurahan Mekarsari adalah Pola Komunikasi Antarpribadi triadik. Pola komunikasi ini adalah merupakan pola komunikasi yang tepat untuk digunakan dalam proses pembelajaran dan sangat berperan pentong dalam menjadikan remaja berakhlakul karimah dalam lingkungan yayasan maupun dilingkungan sehari-hari.
\end{abstract}

Kata Kunci: Pola Komunikasi Guru ngaji dalam membina akhlak remaja. 


\section{A. Pendahuluan}

Komunikasi digunakan sebagai cara untuk memiliki hubungan dengan manusia lainnya, sehingga tidak akan terjadi jika terdapat manusia yang menjalani hidupnya tanpa melakukan komunikasi dengan orang lain. Dikarenakan, tanpa melakukan komunikasi manusia tidak bisa menjalankan fungsinya sebagai pembawa amanah dari Allah di muka bumi (khalifah). Pada umumnya komunikasi yaitu aktivitas dasar yang hakikatnya tidak dapat hidup sendiri melainkan terikat atau saling membutuhkan satu sama lain. Komunikasi dapat mempererat hubungan individu yang satu dengan yang lainnya. Dengan proses komunikasi inilah, manusia melaksanakan kewajibannya.

Dalam kehidupan kita sudah sering ditemukan kegiatan dakwah. Dakwah (da'wah) secara semantik berakar dari kata da'a, yad'u dan da'wat: ajakan, seruan dan panggilan (Ma'luf, 1997: 245). Siapa saja dapat mengajak dan menyeru kepada apa yang diinginkan atau dituju, bahkan syetan pun dapat mengajak golongannya pada kesesatan yang berujung kepada penyesalan. Sedangkan Allah SWT mengajak orangorang yang beriman ke "perkampungan damai' (dār al-salām) yang penuh dengan karunia dan ampunan-Nya.

Sedangkan makna terminologinya adalah 'ajakan kepada suatu kondisi yang baik.' Baik dari suasana yang belum tahu menjadi tahu, maupun dari kondisi yang sudah baik menuju kepada yang lebih baik lagi. Dakwah secara spesifik dimaknakan sebagai suatu ajakan kepada jalan Islam atau kepada Allah SWT, sehingga penerima dakwahnya terbawa kepada Ridha dan pertolongan Allah Swt; agama yang sesuai dengan fitrah manusia.

Banyak tantangan, hambatan dan rintangan menghadang para da'i namun mereka tetap berdakwah dengan kesabaran dan ketawakalan. Da'i berupaya untuk legowo menanggung resiko tindakannya. Da'i merupakan sosok yang unggul di medan dakwahnya, mencari jalan yang ada. Kepribadian da'i dan karakternya ditempa melalui pendidikan dan pelatihan. Semula pendidikan itu dilakukan di pesantren yang bersifat alami, namun setelah memasuki Indonesia merdeka maka pendidikan itu lebih bersifat struktural dan formal.

Pembinaan diri da'i oleh diri sendiri menjadi model bagi peningkatan ruhiyahnya untuk menggapai cita-citanya. Faktor riyadhah (riyalat) ini menjadi kekuatan kepribadian masyarakat pesantren. Para santri berupaya untuk hidup sederhana dan mencukupi kebutuhan dengan upaya dan kondisi yang terbatas. Karena itulah santri menjadi lebih mandiri dibandingkan dengan siswa sekolah umum.

Manusia ialah makhluk sosial yang tidak bisa hidup sendiri mereka saling membutuhkan satu sama lain. Dan tidak bisa dipisahkan. Dalam sudut pandang agama, komunikasi berperan penting bagi kehidupan manusia untuk bersosialisasi dengan lingkungan dan sesamanya. Manusia diharuskan agar mahir dalam berkomunikasi. Hal ini dijelaskan dalam Al-Qur'an surat ar Rahman ayat 1-4

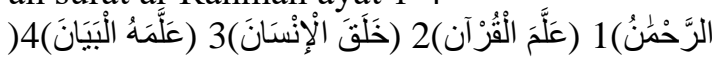

Allah Yang Maha Pengasih, Yang telah mengajarkan Al-Qur'an. Dia menciptakan manusia, mengajarnya pandai berbicara. (Q.S. Ar-Rahman [55]: 1- 4).

Surah ar-Rahman ayat 1-4 menjelaskan bahwa manusia menjadi subjek pendidikan hal ini karena manusia merupakan makhluk ciptaan Allah yang paling sempurna yang telah diberikan olehNya sesuatu yang tidak diciptankan kepada makhluk ciptaannya yang lain.

Masa remaja merupakan masa yang selalu dialami oleh setiap manusia. Namun dalam usia remaja ini manusia sedang mengalami proses pembentukan diri menjadi dewasa. Masa remaja memang masa yang riskan akan kegoncangan jiwa dalam arti pada masa ini merupakan masa yang penuh dengan pengaruh untuk memasuki masa dewasa dari masa anak-anak. Pada usia remaja inilah terjadi proses perubahan menuju kepada proses pematangan kepribadian yang penuh dengan pemunculan sifat-sifat pribadi yang sesungguhnya yang harus berbenturan dengan rangsang dari luar. Benturan-benturan inilah yang sering menimbulkan persoalan bagi remaja yang lemah mental, jiwa dan rohaninya yang kadang-kadang diwujudkan pada suatu tindakan yang menyimpang.

Fenomena remaja di Kelurahan Cimanggis saat ini, sudah mulai terlihat ada pergeseran, semula hanya kenakalan anak remaja yang biasa saja, sekarang masyarakat telah mulai merasakan keresahan yang cenderung merambah segi-segi kriminal yang secara yuridis 
menyalahi ketentuan-ketentuan hukum pidana. Seperti contoh yang sedang terjadi saat ini, yaitu maraknya pembegalan motor dan perampokan yang terjadi di Depok dan Tanggerang serta daerah lainnya, kemudian diketahui pula bahwa identitas beberapa orang pelaku pembegalan dan perampokan masih berusia remaja.

Dunia pendidikan akhir-akhir ini digoncangkan oleh fenomena-fenomena yang kurang menggembirakan terlihat banyaknya tawuran pelajar, pergaulan asusila dikalangan pelajar, pencabulan poronografi tak terbendung. Maka dari itu peran Guru Ngaji sangat penting untuk mengarahkan para remaja kepada hal-hal yang baik, mengarahkan remajanya untuk lebih mengetahui anjuran agama Islam yang sebenarnya. Dan untuk melakukan itu semua tentulah seorang Guru Ngaji harus memiliki keterampilan dalam komunikasi, atau memiliki bentuk komunikasi yang efektif dalam menyampaikan ajaran Islam tersebut.

Seperti halnya yang dilakukan oleh yayasan At-Tibyan dengan melakukan kegiatan pembinaan anak-anak remaja dalam bentuk pengajian yang dilakukan oleh guru-guru ngaji, pengajian tersebut biasanya dilakukan setiap hari Senin-Jum'at dengan tujuan agar anak-anak remaja di yayasan mendapatkan ilmu yang bermanfaat, berakhlakul karimah serta mampu mengamalkannya kelak menjadi generasi yang baik untuk masyarakat.

Adapun tujuan dari penelitian ini adalah:

1. Untuk mengetahui Pola Komunikasi Guru Ngaji dengan Remaja dalam membina Akhlak Remaja di Kelurahan Mekarsari.

2. Untuk mengetahui Akhlak Remaja di Kelurahan Mekarsari.

3. Untuk mengetahui hasil pola komuniaksi Guru Ngaji terhadap Akhlak Remaja di Kelurahan Mekarsari.

\section{B. Metodologi Penelitian}

Pada penelitian ini peneliti menggunakan teori Pola Komunikasi Antarpribadi yang bersifat triadik. Seperti yang diungkapkan oleh Alo Lilliweri bahwa komunikasi antarpribadi merupakan pengiriman pesan dari seseorang dan diterima oleh orang lain dengan efek dan umpan balik yang langsung. Komunikasi ini melibatkan paling sedikit dua orang. Jumlah individu bukanlah yang sembarangan. Jumlah tiga orang dapat dianggap sebagai kelompok terkecil. Antar pribadi dibedakan menjadi dua, yaitu:

1. Komunikasi Diadik adalah komunikasi yang berlangsung antara dua orang dalam situasi tatap muka. Komunikasi diadik dapat dilakukan dalam tiga bentuk, yakni percakapan, dialog dan wawancara.

2. Komunikasi Triadik adalah proses komunikasi yang berlangsung antara tiga orang atau lebih secara tatap muka, dimana anggotanya saling berinteraksi satu sama lainnya.

Berkenaan dengan teori dasar tentang komunikasi antarpribadi triadik, dimana komunikasi ini dilakukan secara langsung dan terdapat tiga anggota atau lebih kemudian menjalin interaksi satu sama lain. Maka di berdasarkan fakta dan data yang di dapat, rangkaian proses tersebut sudah terdapat dalam Yayasan At-Tibyan dimana proses komunikasi dilakukan secara langsung atau tatap muka di ruangan madrasah, dan berlangsung secara tiga orang atau lebih.

\section{Hasil Penelitian dan Pembahasan}

Komunikasi antarprbadi tradik memiliki lima poin pokok yang menjadi acuan dinilai apakah proses komunikasi tersebut berjalan dengan efektif atau tidak. Kelima poin itu adalah:

1. keterbukaan

2. Empati

3. Sikap mendukung

4. Sikap Positif

5. Kesetaraan 
Adapun kenyamanan yang terdapat di Yayasan At-Tibyan nampaknya sudah terbangun, ini bisa dilihat dari keakraban guru ngaji dan murid remaja disana. Bahkan dengan adanya kesetaraan disana bisa membangun rasa pentingnya keberadaan orang lain akan kebutuhan dirinya, kebutuhan murid remaja terhadap ilmu pengetahuan baru serta kebutuhan guru ngaji akan pemanfaatan ilmunya untuk diamalkan sehingga kedunya bisa datang dan bertemu disatu tempat yang sama untuk menjalin komunikasi yang baik dan hal itu sudah terbangun di Yayasan At-Tibyan.

Berkenaan dengan teori dasar tentang komunikasi antarpribadi triadik, dimana komunikasi ini dilakukan secara langsung dan terdapat tiga anggota atau lebih kemudian menjalin interaksi satu sama lain. Maka di berdasarkan fakta dan data yang di dapat, rangkaian proses tersebut sudah terdapat dalam Yayasan At-Tibyan dimana proses komunikasi dilakukan secara langsung atau tatap muka di ruangan madrasah, dan berlangsung secara tiga orang atau lebih. Pola komunikasi yang di gunakan oleh guru ngaji di Yayasan At-Tibyan berdampak terhadap akhlak remaja di Kelurahan Mekarsari, adapun pola komunikasi yang digunakan oleh guru ngaji di Yayasan At-Tibyan adalah komunikasi antar pribadi yang bersifat triadik. Dalam kajian dakwahnya, guru ngaji ditempatkan sebagai $d a^{\prime} i$ dengan memyampaikan materi atau pesan dakwah berupa keilmuan agama dengan mad'u-nya remaja yang menjadi murid di Yayasan At-Tibyan.

Jika meninjau efektifitasnya untuk Yayasan At-Tibyan maka bisa dinilai sukses sebab beberapa syarat dan kriteria sudah terpenuhi. Namun lain halnya jika menilai efektifitasnya dengan teori komunikasi antarpribadi yang bersifat diadik maka akan lebih efektif karena terfokus pada satu orang saja. Maka pola komunikasi antarpribadi triadik yang digunakan oleh guru ngaji di Yayasan At-Tibyan terbilang cukup baik sebab bisa menyasar terhadap banyak komunikan serta bisa melihat perkembangannya.

Akhlak merupakan salah satu khazanah intelektual muslim yang kehadirannya hingga saat ini dirasakan dan sangat diperlukan. Akhlak secara teologis dan historis tampil untuk mengawal dan memandu perjalanan umat Islam agar bisa selamat di dunia dan akhirat. Tentang bagaimana akhlak remaja yayasan At-Tibyan di Kelurahan Mekarsari dalam membina akhlak. Dalam penganalisaan ini peneliti menganalisa tentang hal mengenai apakah akhlak remaja (mad'u) mampu menerima materi yang telah disampaikan oleh guru ngaji (da'i), melalui komunikasi antarpribadi terhadap remaja-remaja yayasan At-Tibyan dengan proses pembelajaran di dalam kelas dengan waktu yang sangat terbatas. Berkaitan dengan sejauh mana pesan atau materi membangkitkan tanggapan yang dikehendaki guru ngaji (da'i) dalam membina akhlak remaja yayasan At-Tibyan dalam berakhlak baik dengan diri sendiri, orang lain dan masyarakat. Yang dimaksud bagaimana akhlak remaja disini adalah bentuk keberhasilan remaja berakhlakul karimah di yayasan At-Tibyan.

Dengan adanya penyampaian materi tentang akhlak yang berkesinambungan, sedikit demi sedikit tentunya akan membuahkan hasil. Hal-hal yang sangat erat kaitannya dengan keberhasilan dalam menyampaikan materi tentang ajaran Islam (Dakwah) lazim disebut sebagai faktor-faktor yang mempengaruhi akhlak, baik factor dari dalam yang melekat pada kegiatan dakwah itu sendiri.

Mendidik para remaja selain menjadi seorang yang pandai bersaing didunia luar juga membina para remaja agar dapat menguasai ilmu agama dan dapat berakhlakul karimah tentunya harus mempunyai strategi dan metode pengajaran yang baik pula. Dan berdasarkan observasi metode yang baik dalam membina akhlak remaja di yayasan At-Tibyan adalah, metode khitobah, dengan cara seorang guru ngaji berbicara didepan remaja menyampaikan materi dengan tutur yang baik agar mampu mempengaruhi para remaja (mad'u) supaya mereka mampu mrngikuti paham yang dianut oleh guru ngaji (komunikator). Selanjutnya menggunakan metode tanya jawab, dengan cara dengan cara soerang guru ngaji dalam menyampaikan materi mengajukan pertanyaan dan para remaja menjawab atau sebaliknya, lalu metode diskusi guru ngaji (komunikator) menghadapkan remaja pada suatu permasalahan. Tujuan utama dari metode diskusi ini adalah untuk memecahkan permasalahan, menjawab pertanyaan dan memahami pengetahuan anak remaja diyayasan. 
Selain masih terdapat remaja yang masih malas dan lebih senang bermain game online. Juga terdapat remaja yang masih berisik dan mengganggu saat jam pembelajaran berlangsung bahkan dalam hasil wawancara ditemukan bahwa masih ada remaja yang saat bertemu dengan guru ngaji masih bersikap cuek. Menjadi dampak negatif dari pola komunikasi yang digunakan ini adalah kurangnya perhatian terhadap remaja secara individu. Sehingga membuat remaja akan merasa lepas dari pantauan guru ngaji.

Telah disajikan bagaimana pola komunikasi yang digunakan oleh guru ngaji di Yayasan At-Tibyan yaitu dengan menggunakan komunikasi antarpribadi triadik. Namun pada praktiknya komunikasi yang digunakan oleh guru ngaji di Yayasan At-Tibyan terbilang tidak efektif mengingat masih adanya remaja yang tidak memiliki akhlak baik. Berdasarkan teori dampak, bahwa berdasarkan sifatnya terbagi menjadi dua yaitu:

1. Dampak Positif

Dampak positif dari pola komunikasi antar pribadi triadik yang digunakan oleh guru ngaji di Yayasan At-Tibyan terhadap akhlak remaja disana adalah meningkatnya kesadaran berbuat baik terhadap guru, orang tua, teman dan lingkungan. Perbuatan baik yang mereka aplikasikan adalah bentuk penerapan dari pesan yang disampaikan oleh guru ngaji $\left(d a^{\prime} i\right)$. Bertambahnya kesadaran ini tentu disertai dengan ilmu pengetahuan yang mereka miliki. Namun dengan bertambahnya pengetahuan tidak serta merta membuat keseluruhan remaja memiliki akhlak yang baik. Ditemukan masih adanya beberapa remaja yang mempunyai sifat malas untuk belajar dirumah dan gemar bermain game online. Artinya perkembangan akhlak remaja setelah mendapat pesan atau materi dari guru ngaji dengan menggunakan pola komunikasi antarpribadi triadik tidaklah signifikan.

Dampak yang terasa dari pola komunikasi yang digunakan oleh guru ngaji di Yayasan At-Tibyan ini adalah kecenderungannya terhadap penyampaian materi yang bisa diterima dengan baik. Serta kedekatan emosional yang terbangun antara guru ngaji ( $\left.d a^{\prime} i\right)$ dan remaja $\left(\operatorname{mad}^{\prime} u\right)$.

2. Dampak Negatif

Sudah menjadi satu keinginan bersama khususnya kalangan pendidik di Yayasan AtTibyan agar bisa menghasilkan mad'u yang ber-akhlakul karimah terhadap diri sendiri, Allah, Orang Tua, guru, teman dan lingkungan sekitar namun hal tersebut belumlah tercapai secara maksimal. Adapun dampak negatif dari pola komunikasi yang digunakan oleh guru ngaji di Yayasan At-Tibyan adalah ketidak signifikannya perkembangan akhlak baik remaja.

Dampak dari pola komunikasi yang digunakan oleh guru ngaji di Yayasan At-Tibyan ini disebabkan juga oleh beberapa gangguan sebagaimana yang telah dibahas. Namun tentunlah untuk mencapai hasil yang maksimal dari sebuah proses komunikasi antara guru ngaji (da'i) dengan remaja (mad'u) haruslah tercapai. Memperbaiki pola komunikasi adalah bagian dari upaya untuk menghilangkan dampak negatif sehingga bisa terciptanya pembinaan akhlak remaja yang baik.

\section{Kesimpulan}

Berdasarkan hasil pembahasan dan anlisis peneliti terkait Pola Komunikasi guru ngaji dalam membina akhlak remaja di yayasan At-Tibyan Kelurahan Mekarsari yang telah dilakukan pada bab sebelumnya, maka peneliti mengambil kesimpulan sebagai berikut:

1. Pola komunikasi antara guru ngaji dengan remaja dalam membina akhlak remaja di yayasan At-Tibyan Kelurahan Mekarsari berdasarkan hasil penelitian yaitu pola komunikasi antarpribadi triadik, sehingga hasil dari pola komunikasi antarpribadi triadik yang digunakan oleh guru ngaji di Yayasan At-Tibyan terbilang efesien sebab bisa menyasar terhadap banyak komunikan serta bisa melihat perkembangannya.

2. Dari penelitian ini juga di ketahui bahwa akhlak remaja di yayasan At-Tibyan masih terdapat remaja yang akhlaknya kurang baik. Karena melihat dari segi akhakul karimahnya masih ada beberapa remaja yang tidak mentaati akhlak yang ada. Hal ini disebabkan karena kurangnya pemahaman mereka dan acuh terhadap apa yang telah 
disampaikan. Adapun upaya yang dilakukan oleh guru ngaji di yayasan At-Tibyan Kelurahan Mekarsari yaitu: Memberikan materi dengan cara teknik khitobah, Diskusi dalam pembelajaran/ pengajian, Tanya jawab pada materi pembelajaran.

3. Dampak praktik pada pola komunikasi guru ngaji kepada remaja di yayasan At-Tibyan terbilang tidak efektif mengingat masih ada remaja yang akhlaknya kurang baik.

\section{Acknowledge}

Berisi ucapan terima kasih kepada pihak-pihak terkait yang membantu penelitian Anda.

\section{Daftar Pustaka}

Dari Buku:

[1] Asmara, T. (1997). Komunikasi Dakwah. Jakarta: Gaya Media Pratama.

[2] Aisyah, St. (2014). Antara Akhlak Etika dan Moral, Makasar: Alauddin Univeristy Press

[3] Ali, S. (2000). Metodelogi Penelitian Agama. Jakarta: Raja Grafindo Persada.

[4] Alim, M. (2006). Pendidikan Agama Islam. Bandung: PT Remaja Rosdakarya.

[5] Anwar, A. (1995). Ilmu Komunikasi (Sebagai Pengantar Ringkas). Jakarta: PT Raja Grafindo Persada.

[6] Anwar, R. (2010). Akhlak Tasawuf. Jakarta: Pustaka Setia.

[7] Arikanto, S. (1995). Dasar-dasar Research. Bandung: Tarsito.

[8] Arikanto, S. (1996). Prosedur Penelitian. Yogyakarta: Rineka Cipta.

[9] Asmara. (1992). Pengantar Studi Akhlak. Jakarta: Rajawali Pers.

[10] Asmara, T. (1997). Komunikasi Dakwah. Jakarta: Gaya Media Pratama.

[11] Budyatna, M. (2012). Teori Komunikasi Antarpribadi. Jakarta: Kencana.

[12] Cangara, H. (2010). Pengantar Ilmu Komunikasi. Jakarta: Rajawali Pers.

[13] Devito, J. A. (1887). Komunikasi Antar Manusia. Jakarta: Profesional Book.

[14] Efendi, O. U. (2000). Dinamika Kimunikasi. Bandung: Remaja Rosadakarya.

[15] Efendi, O. U. (2005). Komunikasi Teori dan Praktek. Bandung: PT Remaja Rosadakarya.

Dari Jurnal:

[16] http://proceeding.unisba.ac.id/index.php/sosial/article/view/1240/pdf

[17] https://journal.uny.ac.id/index.php/humanika/article/view/3649/3122 